\title{
Separation of Functionalized
} 5,6-Disubstituted-1,10-Phenanthroline for
Dye-Sensitized Solar Cell Applications

\author{
Hashem Shahroosvand, ${ }^{1}$ Parisa Abbasi, ${ }^{1}$ Behrouz Notash, ${ }^{2}$ and Leyla Najafi ${ }^{1}$ \\ ${ }^{1}$ Department of Chemistry, University of Zanjan, P.O. Box 45195-313, Zanjan 4537138111, Iran \\ ${ }^{2}$ Chemistry Department, Shahid Beheshti University, G. C., Evin, Tehran 1983963113, Iran \\ Correspondence should be addressed to Hashem Shahroosvand; shahroos@znu.ac.ir
}

Received 30 June 2012; Accepted 13 November 2012

Academic Editor: Keith A. Walters

Copyright (C) 2013 Hashem Shahroosvand et al. This is an open access article distributed under the Creative Commons Attribution License, which permits unrestricted use, distribution, and reproduction in any medium, provided the original work is properly cited.

\begin{abstract}
5,6-Epoxy-1,10-phenanthroline is used as a convenient starting material for 5-hydroxy-6-Aryl-1,10-phenanthroline ligands containing carboxylic and sulfonic groups useful for further anchoring of the sensitizer on $\mathrm{TiO}_{2}$ for dye-sensitized solar cells (DSCs). Based on the crystal growth of the mixture of products, a convenient separation route for the extension of the p-system on 5,6-disubstituted-1,10-phenanthroline was used to develop a novel series of functionalized 1,10-phenanthroline ligands with electron-withdrawing end-capping group. Also, we report the epoxy opening of 5,6-epoxy-1,10-phenanthroline by aromatic amines stoichiometrically in refluxing water and ethanol in the absence of any catalyst. The dyes were characterized by ${ }^{1} \mathrm{H}-\mathrm{NMR}$, FT-IR, UV-Vis, and X-ray single crystal diffraction analyses. It crystallizes in the monoclinic space group $C 2 / c, a=20.920(4) \AA$, $b=$ 10.340(2) $\AA, c=16.187(3) \AA, \beta=92.30(3)^{\circ}, V=3498.6(12) \AA^{3}$, and $Z=8$. The reaction details and features were described in detail.
\end{abstract}

\section{Introduction}

The dye-sensitized nanocrystalline solar cell (DSC) offers special opportunities in the realm of renewable energy sources primarily stemming from its use of low-cost materials and its lack of stringent conditions required for device manufacturing [1]. In a dye-sensitized cell, the immobilization of the sensitizer on the nanocrystalline $\mathrm{TiO}_{2}$ surface allows efficient electronic communication between the lightharvesting center and the semiconductor substrate. The immobilization of the sensitizer is achieved by attaching anchoring groups (e.g., carboxylate [2, 3], sulfonate [4, 5], salicylate [6], phosphonate [7-9], carbonyl [10,11], catechol [12], and acetyl acetonate groups [13]) to the surfaces of the mesoporous $\mathrm{TiO}_{2}$ nanoparticles [14]. To further increase the performances of dye-sensitized solar cell, it is of paramount importance to engineer ligands at a molecular level and thus to endow sensitizers with both panchromatic absorption and a relatively high molar extinction coefficient. Therefore, to accelerate the discovery and improvement of better performing sensitizers, easily accessible strategies for the functionalization of 2,2-bipyridyl (bpy) or 1,10-phenanthroline (phen) derivatives are required [15]. A distinct property of this class of chelating agents, phen and bpy, in particular, is their $\pi$ electron deficiency that makes them excellent $\pi$ acceptors capable of stabilizing metal ions in lower oxidation states. Furthermore, due to the presence of low-energy $\pi^{*}$ orbitals of the ligand, metal complexes can be characterized by strong metal-to-ligand charge-transfer (MLCT) absorption bands in the visible spectrum and red-shifted fluorescent emissions [13-17] which is indicated as suitable ligand for dye-sensitized solar cell application. Due to the combination in phen of these distinct structural and chemical properties, the increasing interest in the chemistry of phen derivatives has prompted the development of efficient synthetic procedures for the chemical fictionalization of the phen nucleus at the various ring positions [18]. The 5- and 6positions of phen are the most susceptible to electrophilic 
substitutions. Reaction with commercial bleach under phasetransfer conditions can afford, in good yield, 5,6-epoxy-1,10phenanthroline which represents a good intermediate for functionalization of the 5-position of phen with different binding sites for analytes [18]. In this paper, we report such an efficient synthetic route for the preparation of a series of symmetrically 5,6-disubstituted-1,10-phenanthroline being endcapped by electron-withdrawing groups. This end-capping diversity will allow us to tune the photophysical properties of the corresponding Ru-based sensitizers in a rational manner.

\section{Experimental}

All chemicals and solvents were purchased from Merck \& Aldrich and used without further purification. IR spectra were recorded on a Perkin-Elmer 597 spectrometer and ${ }^{1} \mathrm{H}$ NMR spectra were recorded by using a Bruker $250 \mathrm{MHz}$ spectrometer.

The X-ray diffraction measurements were made on a STOE IPDS-II diffractometer with graphite monochromated Mo-K $\alpha$ radiation. Cell constants and orientation matrices for data collection were obtained by least-squares refinement of diffraction data from 4711 unique reflections. Data were collected to a maximum $2 \theta$ value of $58.5^{\circ}$ in a series of $\omega$ scans in $1^{\circ}$ oscillations and integrated using the Stoe XAREA [19] software package. The data were corrected for Lorentz and Polarizing effects. The structures were solved by direct methods [20] and subsequent difference Fourier maps and then refined on $F^{2}$ by a full-matrix least-squares procedure using anisotropic displacement parameters [21]. All hydrogen attached to carbon atoms were added in idealized positions and hydrogen atoms of the water molecule, $\mathrm{NH}$ and $\mathrm{NH}_{2}$ group were found in difference Fourier map. All refinements were performed using the X-STEP32 crystallographic software package [22]. A summary of crystal data, experimental details, and refinement results is given in Table 1.

For the synthesis of 5,6-epoxy-1,10-phenanthroline, $1 \mathrm{mmol}$ (198 mg) of phenanthroline, dissolved in $20 \mathrm{~mL}$ of chloroform, is added to $250 \mathrm{~mL}$ of $0.6 \mathrm{M}$ aqueous sodium hypochlorite (commercial bleach), the $\mathrm{pH}$ of which has been adjusted to 8.5 with concentrated $\mathrm{HCl}$. Tetrabutylammonium hydrogen sulfate (0.2-1 equiv) is added and the mixture is stirred at room temperature until TLC indicates that all of the phenanthroline has reacted. The layers are separated and the organic layer is washed with a large excess of cold water, dried, and evaporated at room temperature. The crude epoxide was purified by recrystallization from a mixture of chloroform and hexanes $(5: 1)$ to give a product [23]. For synthesis of $\mathrm{L}_{1}$, the phenanthroline 5,6-epoxide $(100 \mathrm{mg}$, $0.5 \mathrm{mmol}$ ) and 4 -amino-benzenesulfanic acid (A) $(88.53 \mathrm{mg}$, $0.5 \mathrm{mmol}$ ) were taken in a mixture of water and methanol $(50 \mathrm{ml})$ and refluxed for $14 \mathrm{~h}$. After evaporation at room temperature, orange and yellow crystals were appeared. For synthesis of $\mathrm{L}_{2}$ 1,10-phenanthroline-5,6-epoxide (L) $(100 \mathrm{mg}$, $0.5 \mathrm{mmol}$ ) was dissolved in $30 \mathrm{ml}$ of methanol which contained $109 \mathrm{mg}(0.5 \mathrm{mmol})$ of 2-phenylamino-benozic acid
TABLE 1: Crystal data and structure refinement for C18H17N3O4S $\left(\mathrm{L}_{1}^{\prime}\right)$ at $298 \mathrm{~K}$.

\begin{tabular}{lc}
\hline Molecular formula & C18 H17 N3 O4 S \\
Molecular weight & 371.42 \\
Temperature $(\mathrm{K})$ & $298(2)$ \\
Radiation $\lambda(\AA)$ & 0.71073 \\
Crystal system & Monoclinic \\
Space group & $C 2 / c$ \\
$a / \AA$ & $20.920(4)$ \\
$b / \AA$ & $10.340(2)$ \\
$c / \AA$ & $16.187(3)$ \\
$\beta\left(^{\circ}\right)$ & $92.30(3)$ \\
$V / \AA^{3}$ & $3498.6(12)$ \\
$Z$ & 8 \\
$D_{\text {calc }}\left(\right.$ g cm $\left.^{-3}\right)$ & 1.410 \\
Crystal size $($ mm $)$ & $0.25 \times 0.17 \times 0.15$ \\
Crystal colour & Yellow \\
Absorption coefficient $\left(\mathrm{mm}^{-1}\right)$ & 0.215 \\
$F(000)$ & 1552 \\
Reflections collected/unique & $18828 / 4711$ \\
$\theta$ range $\left(^{\circ}\right)$ & $1.95-29.25$ \\
Number of parameters & 253 \\
Number of restraints & 0 \\
Goodness of fit on $F^{2}$ & 1.141 \\
$R_{1}$, w $_{2}[I \geq 2 \sigma(I)]$ & $0.0767,0.1530$ \\
$R_{1}$, w $_{2}($ all data $)$ & $0.1314,0.1775$ \\
Largest difference peak and hole & $0.302,-0.238$ \\
\hline
\end{tabular}

(B). The reactants were refluxed for $14 \mathrm{~h}$. Again, orange and white were yielded.

\section{Results and Discussion}

Reaction of 5,6-epoxy-1,10-phenanthroline with a variety of nucleophiles results in hydroxy-dihydro intermediates that upon dehydration can afford not only 5-substituted phen derivatives useful for further manipulations but also interesting ditopic ligands featuring the phen nucleus derivatized at the 5-position with chelating groups [18]. Based on experimental results, the opening of the strained threemembered epoxy ring usually occurs in nonaqueous media in presence of a Lewis acid catalyst like $\mathrm{Al}_{2} \mathrm{O}_{3}, \mathrm{Li}^{+}, \mathrm{Mg}^{2+}$ [24]. Additionally often elevated temperature and excess of nucleophiles are required. There are a few reports where the use of a catalyst has not been necessary $[25,26]$. For example, aminolysis of epoxide by an a-amino acid ester proceeds smoothly in refluxing trifluoroethanol [25]. The same reactions fail in water. Azizi and Saidi found that the aliphatic and aromatic amines cleave an epoxide ring in water at room temperature without any Lewis acid catalyst [26].

Herein, aminolysis of 5,6-epoxy-1,10-phenanthroline is potential in generating two products. We obtained phen as a minor product also in the reaction of epoxide with aniline group in the standard conditions for preparation of $\mathrm{L}_{1}^{\prime}$ and 


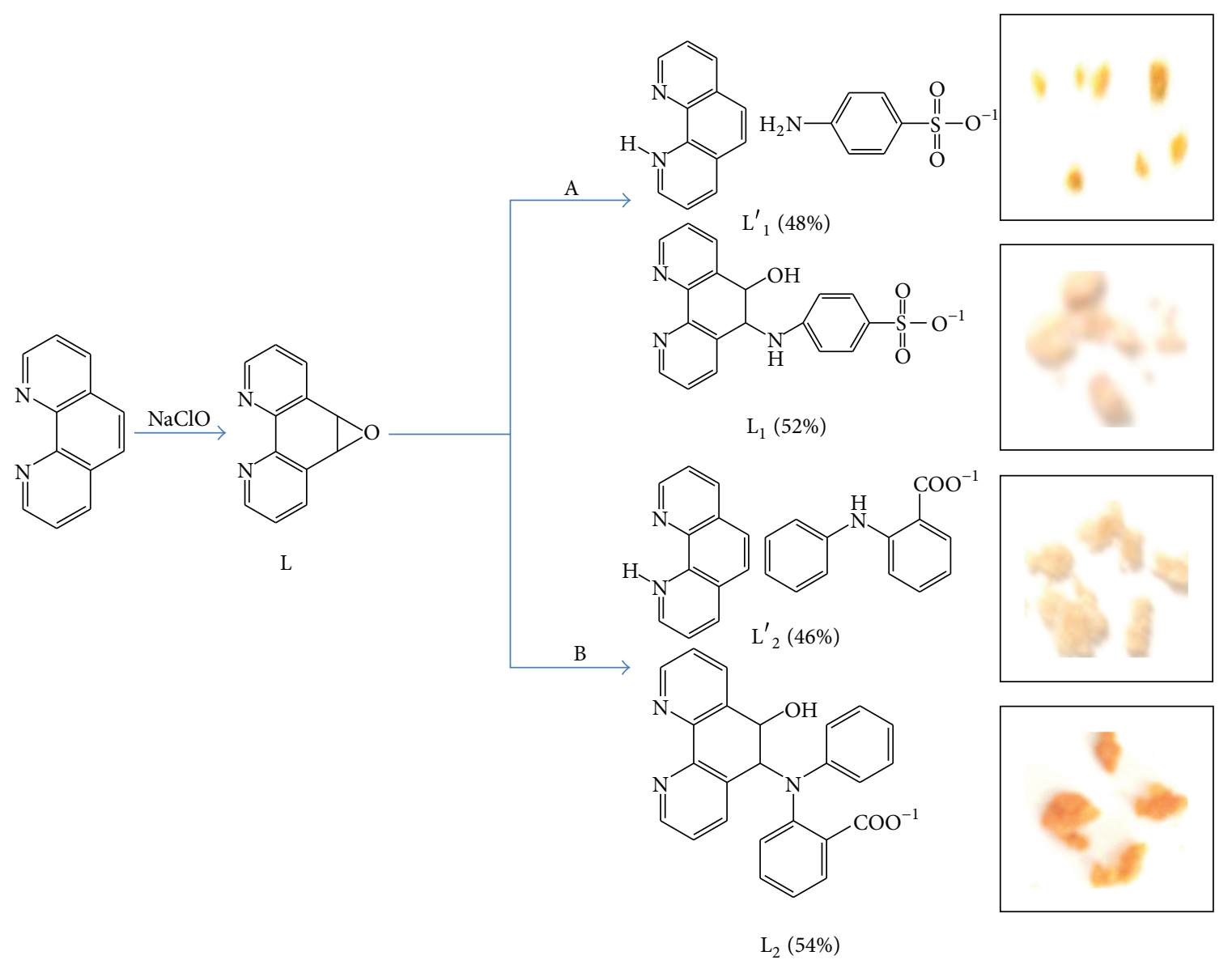

FIGURE 1: Molecular structure of the investigated ligands and the procedure of reactions.

$\mathrm{L}_{2}^{\prime}$ (Figure 1). A plausible mechanism for the deoxygenation may include formation and subsequent denitrogenation of $L_{1}^{\prime}$ and $L_{2}^{\prime}$. The easy denitrogenation at room temperature that we found was apparently stimulated by the aromatization of the central ring as in the case of reactions. Apparently, aromatization of the central ring is a driving force for this elimination [27].

Also, the epoxide ring in 5,6-epoxy-1,10-phenanthroline opens up in its reaction with 4-sonfonyl aniline and 2-[(6-hydroxy)-phenyl-amino]-benzoic acid in water and methanol without any Lewis acid catalyst to give a monohydrate of and 4-(6-hydroxy-5,6-dihydro-[1,10]phenanthro-lin-5-ylamino)-benzenesulfonic $\left(\mathrm{L}_{1}\right)$ acid and 2-[(6-hydroxy-5,6-dihydro- $[1,10]$ phenanthrolin -5-yl) -phenyl-amino]-benzoic $\operatorname{acid}\left(\mathrm{L}_{2}\right)$, respectively (Figure 1 ).

As shown in Figures 2 and 3, the main absorption peaks in the IR spectra of compounds are determined. Generally, in the IR spectrum of the phen, strong bands were observed in frequency region between 1400 and $1650 \mathrm{~cm}^{-1}$, the one band occurring at $1505 \mathrm{~cm}^{-1}$, the second appearing at $1590 \mathrm{~cm}^{-1}$, and the third band at $1423 \mathrm{~cm}^{-1}$. In the present study, IR spectra of $\mathrm{L}_{1}$ and $\mathrm{L}_{2}$ show $v(\mathrm{C}-\mathrm{N})$ band related to phen, at 1422 and $1420 \mathrm{~cm}^{-1}$, respectively, indicating the partial double bond character. The ring frequencies associated with phen are observed at $1497,1601 \mathrm{~cm}^{-1}$ and $1509,1594 \mathrm{~cm}^{-1}$, for $\mathrm{L}_{1}$ and $\mathrm{L}_{2}$. The $v(\mathrm{C}-\mathrm{H})$ of phen bands appear at 2876, $2946,2965 \mathrm{~cm}^{-1}$ and $2885,2941,2970 \mathrm{~cm}^{-1}$, respectively. The (A) compound actually has the zwitterions structure that contains the $-\mathrm{NH}_{3}{ }^{+}$and $-\mathrm{SO}_{3}{ }^{-}$groups. In the IR spectrum of $\mathrm{L}_{1}$, there are a number of bands between $2735 \mathrm{~cm}^{-1}$ and $2735 \mathrm{~cm}^{-1}$ due to combination bands of the $\mathrm{NH}_{3}$ group. The $\mathrm{CH}$ stretching vibration of anilinic ring is observed at 2883, 2905 , and $2921 \mathrm{~cm}^{-1}$ [28]. The $v$ (ph) vibrations are observed at $1601,1578,1547,1422$, and $1319 \mathrm{~cm}^{-1}$. Bands at 1173 , 1037,684 , and $561 \mathrm{~cm}^{-1}$ derive from presence of $\mathrm{SO}_{3}$. The vibration band at 1037 is characteristics of the vibrations of the sulfur atoms linked to the aromatic cycle and of $\mathrm{S}=\mathrm{O}$ symmetric [29]. The asymmetric $\mathrm{S}=\mathrm{O}$ vibration is observed at $1173 \mathrm{~cm}^{-1}$. It is important to note, the disappearance of $v$ $\left(\mathrm{NH}_{2}\right)$ stretching frequency of amine group and appearance of $v(\mathrm{NH})$ stretching at $3445 \mathrm{~cm}^{-1}$ in the IR spectrum of $\mathrm{L}_{1}$ reveals the formation of $\mathrm{L}_{1}$ (Figure 2). 


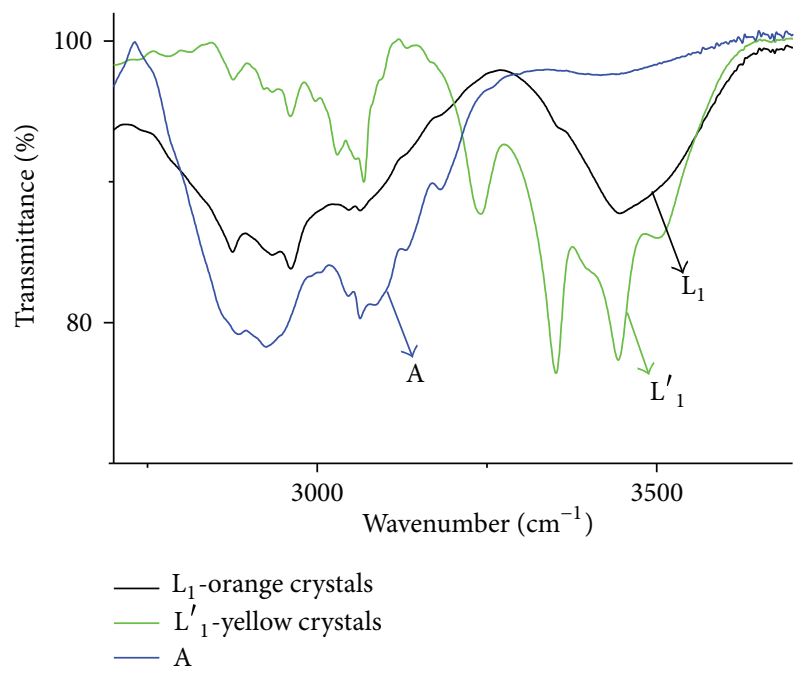

Figure 2: FT-IR spectra of $\mathrm{L}_{1}, \mathrm{~L}_{1}^{\prime}$, and (A) ligands.

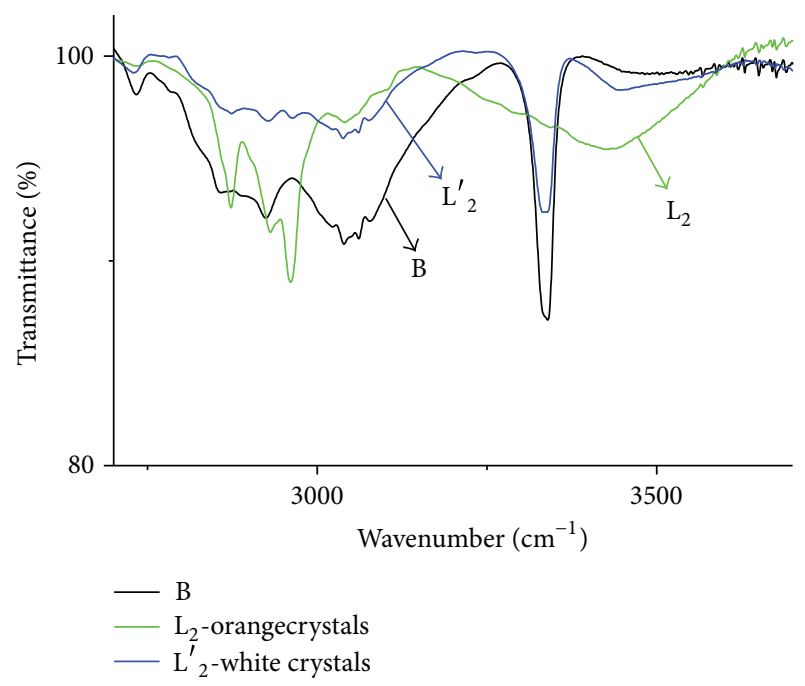

FIGURE 3: FT-IR spectra of $\mathrm{L}_{2}, \mathrm{~L}_{2}^{\prime}$, and (B) ligands.

Two significant vibrations at 1659 and 1262 occur in IR spectrum of $\mathrm{L}_{2}$. The band at $1659 \mathrm{~cm}^{-1}$ is attributed to the $\mathrm{C}=\mathrm{O}$ stretching vibration of the carboxyl group and that $1259 \mathrm{~cm}^{-1}$ can be ascribed to the $\mathrm{C}-\mathrm{N}$ stretching vibration. The $\mathrm{N}-\mathrm{H}$ stretching vibration at $3339 \mathrm{~cm}^{-1}$ was removed. These results suggest that (B) was linked to L (Figure 3).

The UV-Vis absorption spectra of the compound in ethanol solution are given in Figures 4 and 5. Phen is characterized in aqueous solution by UV absorption at 229 and $265 \mathrm{~nm}$, the latter attributed to $\pi-\pi^{*}$ transition to the lowest-energy excited singlet state, $\pi-\pi^{*}$. The absorption band at $230 \mathrm{~nm}$ of $\mathrm{L}_{1}$ and $229 \mathrm{~nm}$ of $\mathrm{L}_{1}^{\prime}$ are the characteristic of the phen. The absorption band of $\mathrm{L}_{1}$ at $265 \mathrm{~nm}$ shows blue shift to 255, may be due to being overlapped with that of (A) at $249 \mathrm{~nm}$.

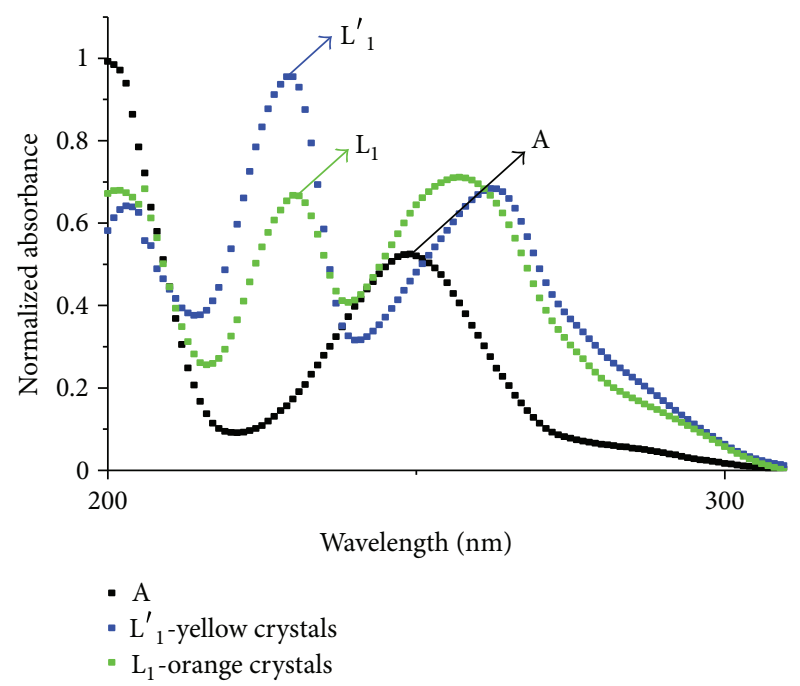

FIgURE 4: Normalized absorption spectra of $\mathrm{L}_{1}, \mathrm{~L}_{1}^{\prime}$, and (A) ligands.

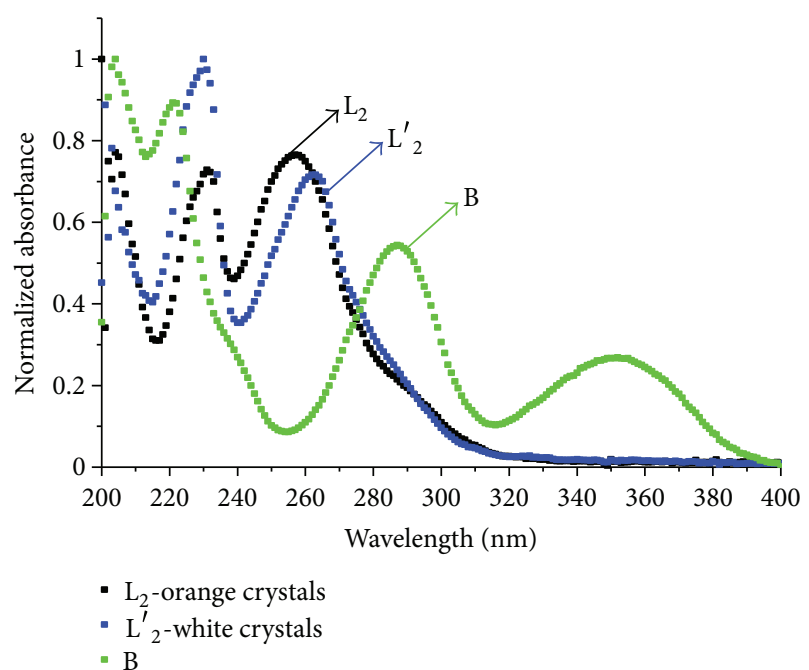

FIGURE 5: Normalized absorption spectra of of $\mathrm{L}_{2}, \mathrm{~L}_{2}^{\prime}$, and (B) ligands.

In the UV-Vis spectra of $\mathrm{L}_{2}$ and $\mathrm{L}_{2}^{\prime}$, two absorption bands were observed at $230,257 \mathrm{~nm}$ and $229,262 \mathrm{~nm}$, respectively. These bands are characterized to the $\pi-\pi^{*}$ transition of the phen rings. But the band at $265 \mathrm{~nm}$, due to the lowestenergy singlet state, shifts to $257 \mathrm{~nm}$ in spectrum of $\mathrm{L}_{2}$. These absorption bands are good evidence for presence of $L$ in the product. In ${ }^{1} \mathrm{H}$ NMR spectra of $\mathrm{L}_{1}$, the protons of phen give signals at $8.06,8.87$, and $9.21 \mathrm{ppm}$ which are slightly deshielded. The signal observed at $7.4 \mathrm{ppm}$ is assigned to the $\mathrm{H}_{\mathrm{f}}$ present in $\mathrm{L}_{1}$. Other proton of anilinc ring, $\mathrm{H}_{\mathrm{e}}$, is slightly shielded and is observed in the upfield region at $6.76 \mathrm{ppm}$. These observed changes show the formation of $\mathrm{L}_{1}$ as shown in Figure 5. 


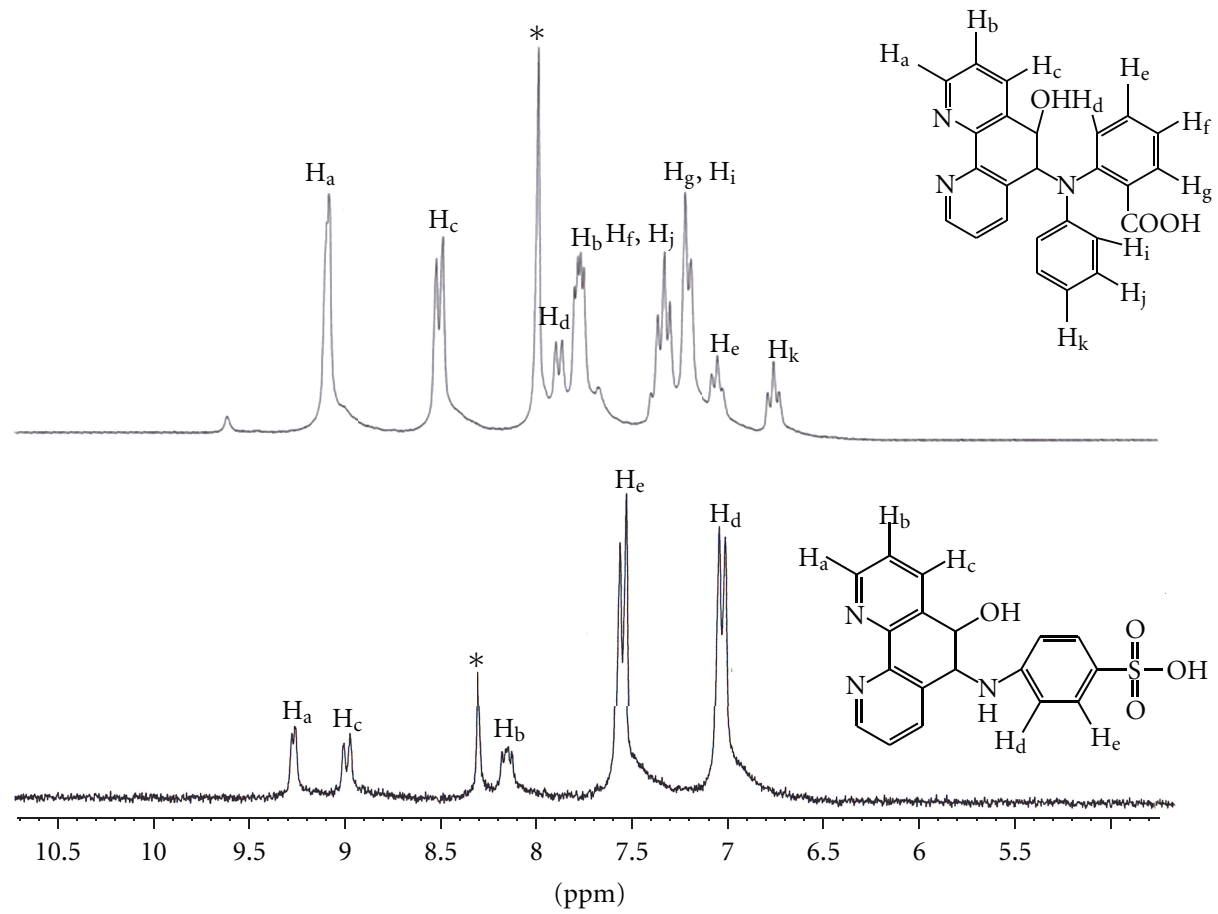

Figure 6: ${ }^{1} \mathrm{H}-\mathrm{NMR}$ spectra of aromatic region of $\mathrm{L}_{1}$ and $\mathrm{L}_{2}$ dissolved in DMSO solvent at room temperature.
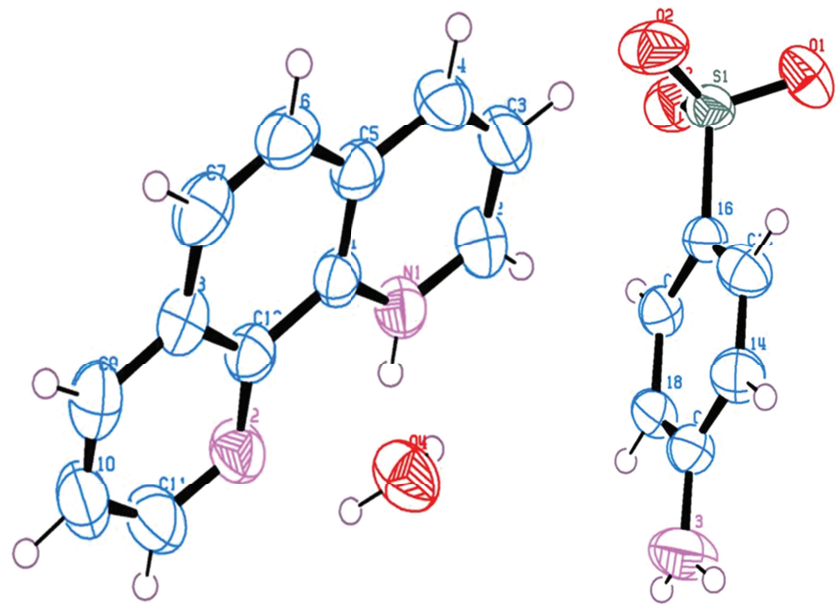

FIGURE 7: ORTEP of $\mathrm{L}_{1}^{\prime}$ with the numbering scheme. Thermal ellipsoids are at the $50 \%$ probability level.

For $\mathrm{L}_{2},{ }^{1} \mathrm{H}$ NMR signals around 7.77, 8.48, and 9.08 ppm arise from the phen protons (Figure 6). The signals of $\mathrm{H}_{\mathrm{d}}$ are deshielded due to the $\mathrm{SO}_{3}$ group and observed at $7.86 \mathrm{ppm}$. The proton signals of the $\mathrm{H}_{\mathrm{g}}, \mathrm{H}_{\mathrm{i}}$ and $\mathrm{H}_{\mathrm{f}}, \mathrm{H}_{\mathrm{j}}$ appear at 7.20 and $7.31 \mathrm{ppm}$, respectively. The signals at 6.75 and $7.05 \mathrm{ppm}$ are associated to $\mathrm{H}_{\mathrm{e}}$ and $\mathrm{H}_{\mathrm{k}}$. All of these signals indicate that the production of $\mathrm{L}_{2}$ is occurred.

The molecular structure of $\mathrm{L}_{1}^{\prime}$ and the atom-numbering scheme are shown in Figure 7.

There are $\mathrm{C}-\mathrm{H} \cdots \pi$ interactions and also different weak hydrogen bonds (Table 2), stabilizing the three-dimensional crystal structure. Significant $\pi-\pi$ interactions are found in the crystal structure.

To gain further insight into the electron density distribution within the frontier and other close lying orbitals, we performed quantum chemical calculations on the $\mathrm{L}_{1}$ using density functional theory (DFT) as shown in Figure 8. The simulations have been performed with the Gaussian 09 program. The level of LAN L2DZ was carried out. In the dye-sensitized solar cells, the LUMO of the dye must be sufficiently high in energy to promote efficient charge injection into the semiconductor film and the HOMO should be sufficiently low in energy for efficient regeneration of the oxidized dye by the hole transport material. Figure 8 shows schematic representation of frontier orbitals of $\mathrm{L}_{1}$, along with isodensity plots of $\mathrm{HOMO}, \mathrm{HOMO}^{-1}$ and LUMO, $\mathrm{LUMO}^{+1}$ orbitals. Here, the chemical structures of the phen and amino benzene solfonic acid have an important effect on the electronic properties of the $\mathrm{L}_{1}$. The $\mathrm{L}_{1}$ presents a HOMO-LUMO energy gap of $4.48 \mathrm{eV}$ significantly larger than the gap calculated for many dye-sensitized solar cell. In the ground state, the electron density of $\mathrm{L}_{1}$ for the highest occupied molecular orbital (HOMO) and $\mathrm{HOMO}^{-1}$ is shared by the phenyl moiety of phen and amino benzene solfonic group. Whereas the LUMO resides on the phen for $\mathrm{L}_{1}$ and shows no overlap with the amino benzene solphonic group. The predicted effect is an increase of the HOMO-LUMO gap of $\mathrm{L}_{1}$, which is in good agreement with the experimental observations. As shown in the figures, these energy levels are able to inject energetic electrons into the conduction band of $\mathrm{TiO}_{2}$.

Further work on the photovoltaic performance of 5,6-functionalized 1,10-phenanthroline is in progress, and 


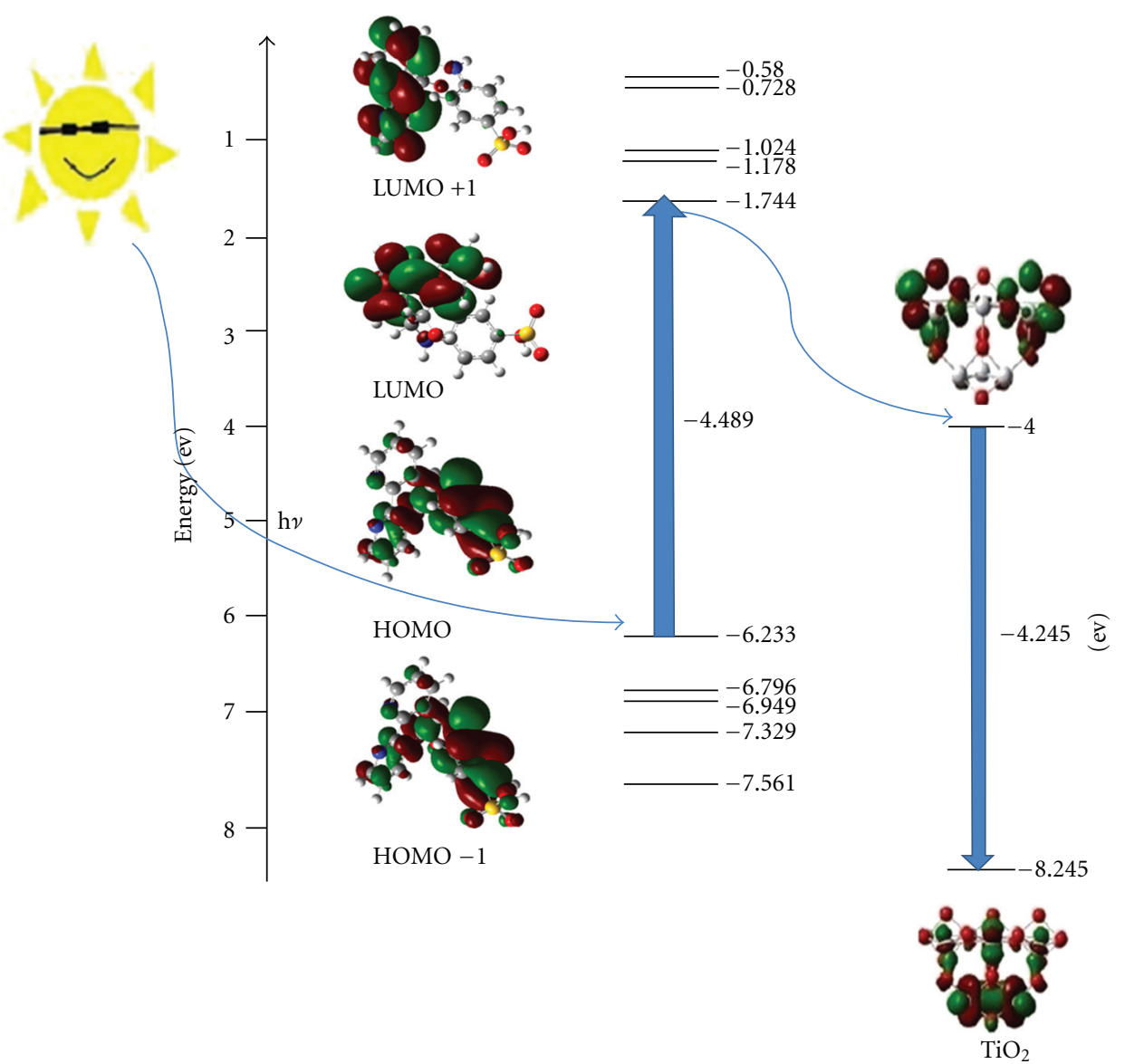

FIGURE 8: Schematic representation of frontier orbitals of $\mathrm{L}_{1}$, along with isodensity plots of HOMO, HOMO -1 and LUMO, LUMO +1 orbitals.

TABLE 2: Hydrogen bond parameters for $L_{1}^{\prime}[\AA ̊$ and deg.].

\begin{tabular}{lcccc}
\hline $\mathrm{D}-\mathrm{H} \cdots \mathrm{A}$ & $d(\mathrm{D}-\mathrm{H})$ & $d(\mathrm{H} \cdots \mathrm{A})$ & $d(\mathrm{D} \cdots \mathrm{A})$ & $<(\mathrm{DHA})$ \\
\hline $\mathrm{N}(1)-\mathrm{H}(1 \mathrm{~A}) \cdots \mathrm{O}(4)$ & $0.89(3)$ & $1.88(3)$ & $2.721(4)$ & $157(3)$ \\
$\mathrm{N}(3)-\mathrm{H}(3 \mathrm{~A}) \cdots \mathrm{O}(2) \# 1$ & $0.76(4)$ & $2.32(4)$ & $3.027(5)$ & $139(4)$ \\
$\mathrm{N}(3)-\mathrm{H}(3 \mathrm{~B}) \cdots \mathrm{O}(2) \# 2$ & $0.93(7)$ & $2.12(7)$ & $2.929(4)$ & $166(6)$ \\
$\mathrm{O}(4)-\mathrm{H}(4 \mathrm{~A}) \cdots \mathrm{O}(1) \# 3$ & $0.90(6)$ & $2.12(6)$ & $2.848(4)$ & $149(4)$ \\
$\mathrm{O}(4)-\mathrm{H}(4 \mathrm{~B}) \cdots \mathrm{O}(1) \# 4$ & $0.79(5)$ & $2.06(5)$ & $3.168(4)$ & $171(5)$ \\
$\mathrm{C}(2)-\mathrm{H}(2) \cdots \mathrm{O}(3) \# 4$ & 0.93 & 2.25 & $3.321(4)$ & 169.3 \\
$\mathrm{C}(4)-\mathrm{H}(4) \cdots \mathrm{O}(2) \# 5$ & 0.93 & 2.41 & & 165.4 \\
\hline
\end{tabular}

Symmetry transformations used to generate equivalent atoms:

$\# 1-x+1 / 2, y-1 / 2,-z+1 / 2 ; \# 2 x,-y+1, z+1 / 2 ; \# 3 x-1 / 2, y-1 / 2, z$

$\# 4-x+1 / 2,-y+1 / 2,-z ; \# 5-x+1 / 2,-y+3 / 2,-z$.

we believe improvements can be achieved by a thorough optimization of ruthenium complexes with respect to, for example, other functionalized 5,6-functionalized 1,10phenanthroline.

\section{Conclusion}

In summary, two new symmetrically 5,6-functionalized 1,10phenanthroline bidentate ligands have been synthesized from 5,6-epoxy-1,10-phenanthroline and carboxyl and sulfonyl aryl ligands. This easy and convenient synthetic strategy allowed us to introduce either electron-withdrawing anchoring groups on the $\mathrm{p}$-conjugated-phenanthroline core. Those ligands have potential for ruthenium sensitizer for dyesensitized solar cells. ${ }^{1} \mathrm{H}$ NMR analysis revealed that all the new synthesized ligands were exclusively obtained. Synthesized dye can be relieved by disappeared amine group in FT-IR spectra. This simple synthetic approach is expected 
to expedite the development of antenna-type ligands for ruthenium sensitizers.

\section{Disclosure}

Crystallographic data for the title compound has been deposited to the Cambridge Crystallographic Data Centre (CCDC no. 888674). Copies of available materials can be obtained free of charge on application to the Director, CCDC, 12 Union Road, Cambridge CB2 IEZ, UK.

\section{Acknowledgment}

This work was supported by grants from the University of Zanjan.

\section{References}

[1] B. O’Regan and M. Grätzel, "A low-cost, high-efficiency solar cell based on dye-sensitized colloidal $\mathrm{TiO}_{2}$ films," Nature, vol. 353, no. 6346, pp. 737-740, 1991.

[2] K. Hara, H. Sugihara, Y. Tachibana et al., "Dye-sensitized nanocrystalline $\mathrm{TiO}_{2}$ solar cells based on ruthenium(II) phenanthroline complex photosensitizers," Langmuir, vol. 17, no. 19, pp. 5992-5999, 2001.

[3] M. K. Nazeeruddin, A. Kay, I. Rodicio et al., "Conversion of light to electricity by cis-X2bis $\left(2,2^{\prime}\right.$-bipyridyl- 4,4 ' dicarboxylate)ruthenium(II) charge-transfer sensitizers (X = Cl-, Br-, I-, CN-, and SCN-) on nanocrystalline $\mathrm{TiO}_{2}$ electrodes," Journal of the American Chemical Society, vol. 115, no. 14, pp. 6382-6390, 1993.

[4] Z.-S. Wang, F.-Y. Li, and C.-H. Huang, "Photocurrent enhancement of hemicyanine dyes containing $\mathrm{RSO}_{3}$ group through treating $\mathrm{TiO}_{2}$ films with hydrochloric acid," Journal of Physical Chemistry B, vol. 105, no. 38, pp. 9210-9217, 2001.

[5] F.-Y. Li, J. Zheng, C. H. Huang et al., "Novel multifunctional umbrella molecule material combining photoelectric conversion and second-order optical nonlinearities in LangmuirBlodgett monolayers," Journal of Physical Chemistry B, vol. 104, no. 21, pp. 5090-5095, 2000.

[6] F. Campus, P. Bonhôte, M. Grätzel, S. Heinen, and L. Walder, "Electrochromic devices based on surface-modified nanocrystalline $\mathrm{TiO}_{2}$ thin-film electrodes," Solar Energy Materials and Solar Cells, vol. 56, no. 3-4, pp. 281-297, 1999.

[7] P. Péchy, F. P. Rotzinger, M. K. Nazeeruddin et al., "Preparation of phosphonated polypyridyl ligands to anchor transition-metal complexes on oxide surfaces: application for the conversion of light to electricity with nanocrystalline $\mathrm{TiO}_{2}$ films," Journal of the Chemical Society, Chemical Communications, no. 1, pp. 65-66, 1995.

[8] S. M. Zakeeruddin, M. K. Nazeeruddin, P. Pechy et al., "Molecular engineering of photosensitizers for nanocrystalline solar cells: synthesis and characterization of Ru dyes based on phosphonated terpyridines," Inorganic Chemistry, vol. 36, no. 25, pp. 5937-5946, 1997.

[9] P. Wang, C. Klein, J. E. Moser et al., "Amphiphilic ruthenium sensitizer with 4,4'-diphosphonic acid-2,2' -bipyridine as anchoring ligand for nanocrystalline dye sensitized solar cells," Journal of Physical Chemistry B, vol. 108, no. 45, pp. 17553-17559, 2004.
[10] H. Shahroosvand, M. Khorasani-Motlagh, M. Noroozifar, M. Shabani, A. Fyezbakhsh, and M. Abdouss, "Synthesis and characterisation of $\mathrm{TiO}_{2}$ nanoparticle with polypyridily complexes for using in solar cells," International Journal of Nanomanufacturing, vol. 5, no. 3-4, pp. 352-365, 2010.

[11] H. Shahroosvand, P. Abbasi, M. Ameri, and M. R. R. Dehkordi, "Dye-sensitized nanocrystalline $\mathrm{ZnO}$ solar cells based on ruthenium(II) phendione complexes," International Journal of Photoenergy, vol. 2011, Article ID 634147, 10 pages, 2011.

[12] C. R. Rice, M. D. Ward, M. K. Nazeeruddin, and M. Gratzel, "Catechol as an efficient anchoring group for attachment of ruthenium-polypyridine photosensitisers to solar cells based on nanocrystalline $\mathrm{TiO}_{2}$ films," New Journal of Chemistry, vol. 24, no. 9, pp. 651-652, 2000.

[13] T. A. Heimer, S. T. D’Arcangelis, F. Farzad, J. M. Stipkala, and G. J. Meyer, "An acetylacetonate-based semiconductor-Sensitizer linkage," Inorganic Chemistry, vol. 35, no. 18, pp. 5319-5324, 1996.

[14] C. Baik, D. Kim, M. S. Kang et al., "Organic dyes with a novel anchoring group for dye-sensitized solar cell applications," Journal of Photochemistry and Photobiology A, vol. 201, no. 23, pp. 168-174, 2009.

[15] C. Klein, E. Baranoff, M. K. Nazeeruddin, and M. Grätzel, "Convenient synthesis of functionalized 4,4'-disubstituted2,2 - bipyridine with extended $\pi$-system for dye-sensitized solar cell applications," Tetrahedron Letters, vol. 51, no. 47, pp. 6161-6165, 2010.

[16] A. Juris, V. Balzani, F. Barigelletti, S. Campagna, P. Belser, and $\mathrm{A}$. von Zelewsky, "Ru(II) polypyridine complexes: photophysics, photochemistry, eletrochemistry, and chemiluminescence," Coordination Chemistry Reviews C, vol. 84, pp. 85-277, 1988.

[17] N. Armaroli, "Photoactive mono- and polynuclear $\mathrm{Cu}(\mathrm{I})$ phenanthrolines. A viable alternative to $\mathrm{Ru}(\mathrm{II})$-polypyridines?" Chemical Society Reviews, vol. 30, no. 2, pp. 113-124, 2001.

[18] A. Bencini and V. Lippolis, "1,10-Phenanthroline: a versatile building block for the construction of ligands for various purposes," Coordination Chemistry Reviews, vol. 254, no. 17-18, pp. 2096-2180, 2010.

[19] Stoe \& Cie, X-AREA: Program for the Acquisition and Analysis of Data, Version 1.30, Stoe \& Cie GmbH, Darmatadt, Germany, 2005.

[20] G. M. Sheldrick, SHELX97. Program For Crystal Structure Solution, University of Göttingen, Göttingen, Germany, 1997.

[21] G. M. Sheldrick, SHELX97. Program for Crystal Structure Refinement, University of Göttingen, Göttingen, Germany, 1997.

[22] Stoe \& Cie, X-STEP32: Crystallographic Package, Version 1.07b, Stoe \& Cie GmbH, Darmstadt, Germany, 2000.

[23] Y. Shen and B. P. Sullivan, "A versatile preparative route to 5substituted-1,10-phenanthroline ligands via 1,10-phenanthroline 5,6-epoxide," Inorganic Chemistry, vol. 34, no. 25, pp. 6235-6236, 1995.

[24] N. K. Shee, F. A. Oluwafunmilayo Adekunle, D. Das, M. G. B. Drew, and D. Datta, "Epoxide ring opening in a zinc(II) complex in water without any Lewis acid catalyst: formation of only one diastereomer out of $2^{3}$," Inorganica Chimica Acta, vol. 375, no. 1, pp. 101-105, 2011.

[25] C. Philippe, T. Milcent, B. Crousse, and D. Bonnet-Delpon, "Non Lewis acid catalysed epoxide ring opening with amino acid esters," Organic and Biomolecular Chemistry, vol. 7, no. 10, pp. 2026-2028, 2009. 
[26] N. Azizi and M. R. Saidi, "Highly chemoselective addition of amines to epoxides in water," Organic Letters, vol. 7, no. 17, pp. 3649-3651, 2005.

[27] I. A. Dotsoenko, M. Curtis, N. M. Samoshina, and V. V. Samoshin, "Convenient synthesis of 5-aryl(alkyl)sulfanyl1,10-phenanthrolines from 5,6-epoxy-5,6-dihydro-1,10-phenanthroline, and their activity towards fungal $\beta$-d-glycosidases," Tetrahedron, vol. 67, no. 39, pp. 7470-7478, 2011.

[28] C. Y. Panicker, H. T. Varghese, P. L. Anto, and D. Philip, "Potential dependent SERS profile of sulfanilic acid on silver electrode," Journal of Raman Spectroscopy, vol. 37, no. 8, pp. 853-857, 2006.

[29] K. Nakamato, Infrared and Raman Spectra of Inorganic and Coordination Compounds Part II: Application in Coordination, Organometallic and Bioinorganic, JohnWiley \& Sons, New York, NY, USA, 1997. 

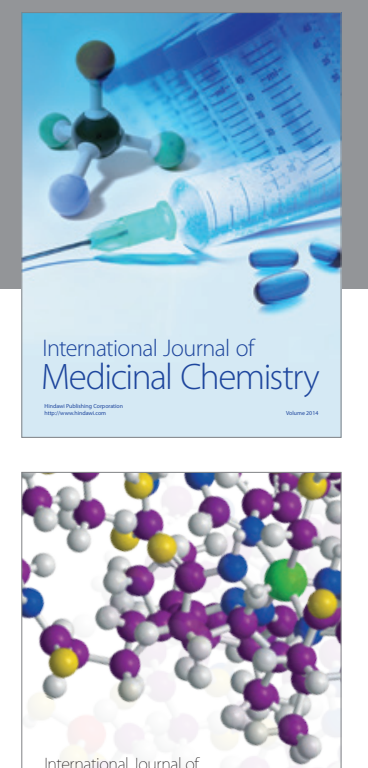

\section{Carbohydrate} Chemistry

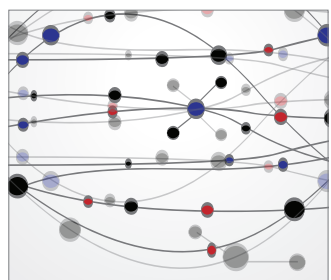

The Scientific World Journal
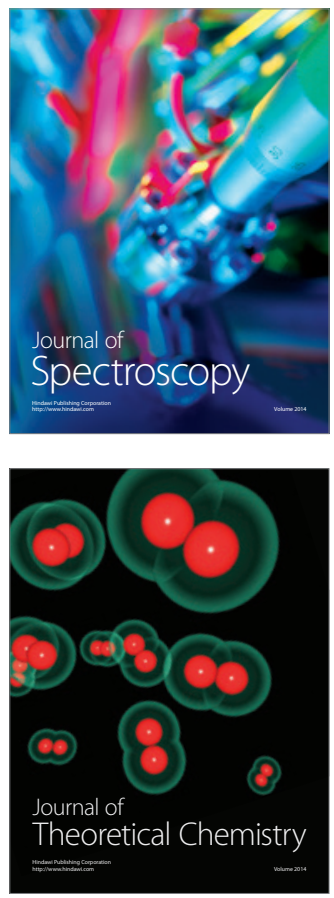
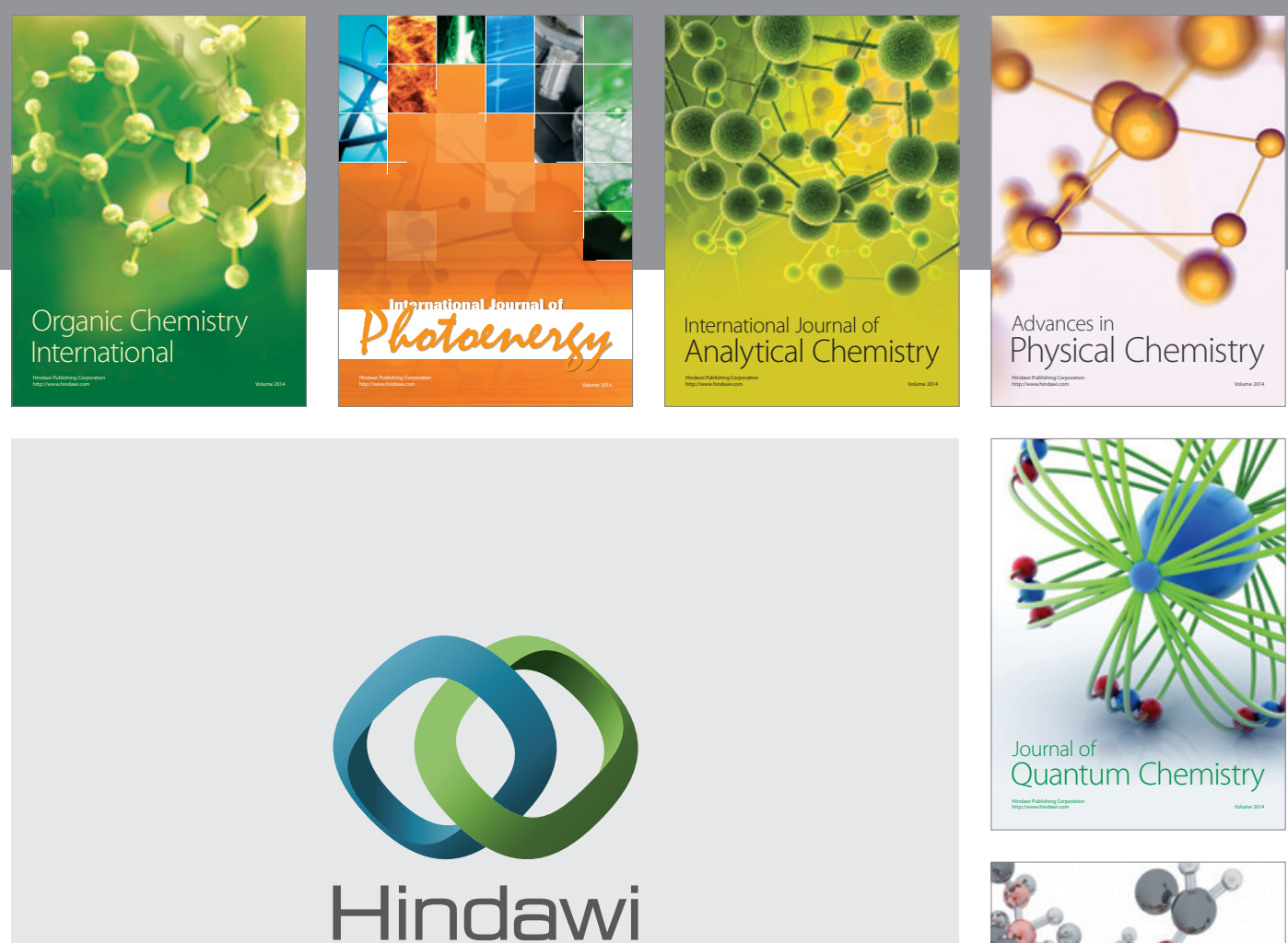

Submit your manuscripts at

http://www.hindawi.com

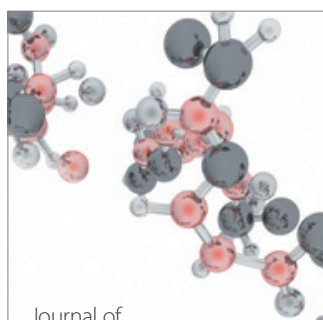

Analytical Methods

in Chemistry

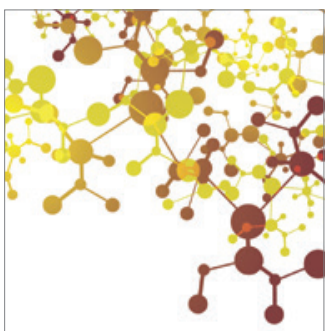

Journal of

Applied Chemistry

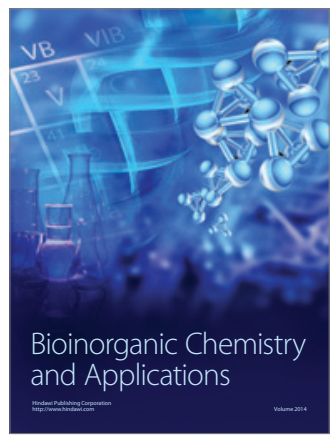

Inorganic Chemistry
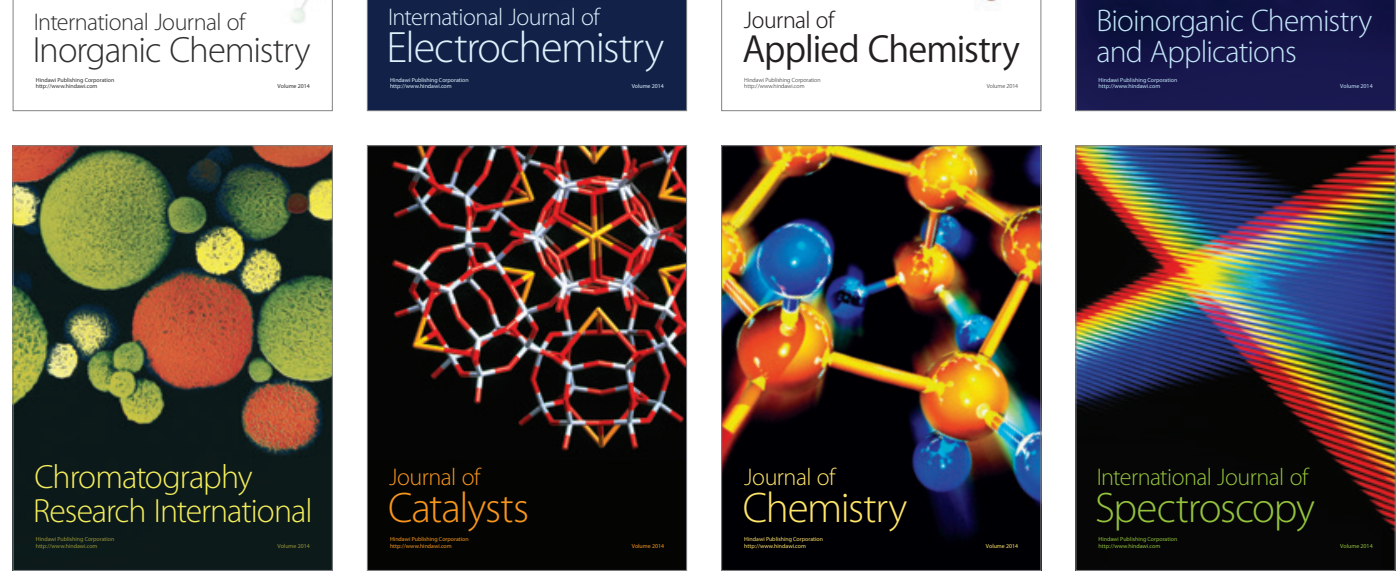